\title{
European Security in the Context of Migration - Measures to Protect Borders and Security Aspects Connected with Migration
}

\author{
Ing. Juraj Kesel \\ Armed Forces Academy of General Milan Rastislav Štefánik, \\ Liptovský Mikuláš, Slovakia
}

Doi: 10.19044/esj.2017.v13n35p62 URL:http://dx.doi.org/10.19044/esj.2017.v13n35p62

\begin{abstract}
The aim of this article is to assess the existing development of migrant crisis in connection with the divided member states of the European Union. Based on the comparison of migrant flows, study of the measures adopted in order to prevent migration and analysis of security risks of migration presented in the article it has been proven that there is a direct correlation between migration and an increased rate of terrorist attacks in Europe. The elimination of smuggling groups and the support of migrants' countries of origin have helped to mitigate migration pressure. The outcomes of the article confirm that despite the adoption of legal and technical measures by the European Union in order to secure the external border of the Schengen Area, European countries do not share the same view of how to solve the migrant crisis. The outcome of migration issue solution is to provide relevant information to the expert public in order to support a stable and safe European Union. It is an equal partnership of all the European Union member states in all the areas that is of the highest priority in order to guarantee the above state.
\end{abstract}

Keywords: Migration, terrorism, safety

\section{Introduction}

Players' interests, climatic changes and the natural Homo Sapiens's feature to improve its living conditions have taken migration-related issues to the top of the world's most discussed issues list. The pursuit of economic growth, competing in having better armaments, ever increasing consumption-oriented life style and other for everyday life 'unnecessary' activities have been gradually taking its price in the form of planet destruction manifested by extreme weather changes. The fear of loss of property and personal safety is being spread by media which has only 
supported the opinion of' those 'more sophisticated' Homo sapiens who think it is wise to withdraw into their integrity. On the other hand, migration brings new opportunities for changes in the lives of those who have not been that fortunate and have not had peaceful and satisfactory lives. Homo sapiens migrates for economic or existential reasons when being forced to leave their homes due to wars, unbearable climatic conditions or social and religious prosecution.

In a wider context, Europe has been perceived as one of safer and more stable regions of the world. Europe's economic growth, standard of living, social security systems, its widespread modern way of living and mild climatic conditions make migrants from third countries see this region as an ideal place. In order to achieve this goal they do not hesitate to entrust smugglers with their lives and walk hundreds of kilometers or sail the seas. As a response to this influx of people stricter security measures that are in accordance with ethical and humanitarian principles have been adopted. There are fences being built at borders. In some cases, the frontier checks were renewed and sea waters more intensely guarded by armed forces. Treaties concerning the reduction of migration are being signed and aid is provided to the affected states from which migrants come or through which they pass. This is one of the ways how Europe responds to security threats having the form of violence and terrorism, which have come hand in hand with the waves of migrants.

\section{Migration as a Phenomenon Polarizing Europe}

The Great Migrant Crisis that has been in Europe since 2015 has been using well-proven migratory routes. These can be in general divided into land and sea migratory routes. In the case of sea routes the overcoming of the final phase of migrants' journey before entering European Union (EU) countries mostly happens on the sea. Unlike the above sea routes, land routes represent almost exclusively mainland roads, except for short sections when migrants pass land waters.

There were three main routes of illegal migration for migrants heading for the EU before the migrant crisis: SOUTH ROUTE (from Africa through the Mediterranean Sea to Spain, France and Italy), SOUTH-EAST ROUTE (through Turkey, the Balkan and states of the former Yugoslavia) and, from the perspective of the Slovak Republic the most significant NORTH ROUTE (from Asia through Russia, Ukraine to the Slovak territory and other EU countries). The final destination for most migrants was the rich states of Western Europe ${ }^{1}$ (Germany, France etc.). These routes have been

\footnotetext{
${ }^{1}$ The states of the Central and Eastern Europe show several common indicators. They are generally known for their politicians and public not being willing to accept refugees. The measures adopted during the migrant crisis mostly focused on better border protection and
} 
modified due to gradual changes in frontier, political, international and security conditions. The original NORTH ROUTE is no longer used in the context of the current migrant crisis. Migrants have found a new north route to get to Europe passing Scandinavian countries, especially Sweden. The most frequently used migratory routes can be seen in Fig. 1.

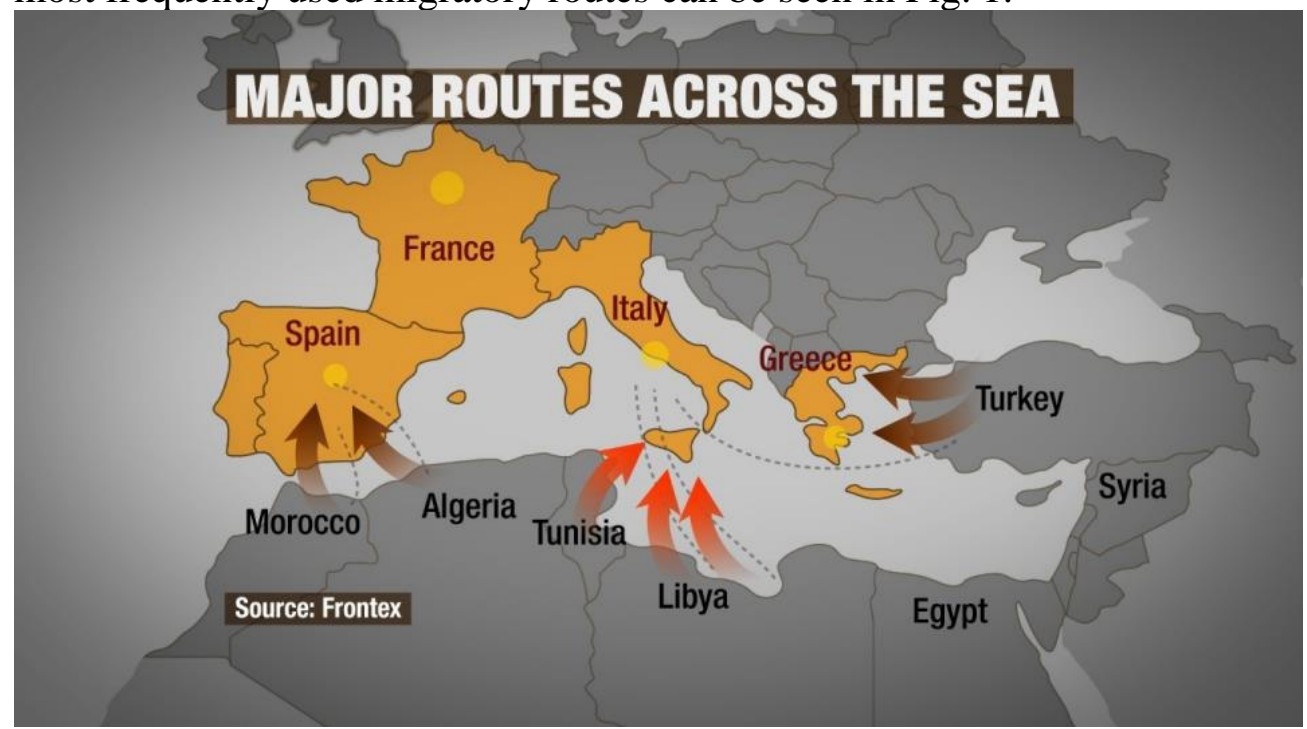

Fig. 1: Sea routes most frequently used by migrants. (Source: Dosani, 2015)

It was the Balkan route that has changed the most by accepting the measures focused on state borders. The countries that played an important role as entrance gates for migrants on this route were Turkey and Greece. The pressure of migration mostly affected Hungary, Greece, Macedonia, Austria and, naturally, Germany, which was migrants' final destination. From regional perspective (the V4 countries), the wave of migrants got closest to Slovakia thanks to its border with Hungary, which responded to this situation by suspending the Dublin Convention and building a fence on the border with Serbia and Croatia. Due to the migrant crisis, the Hungarian government declared the state of emergency in two southern areas neighbors with Serbia thus strengthening the power of the police and other state authorities. This state in Hungary made it possible to send the military forces to help the police guard the border or to do other activities connected with incoming migrants.

For Europe most significant SOUTH ROUTE is considered to be the most dangerous in the world. According to IOM, 14,500 migrants died 
taking this route in 2014. Unlike in 2014, it was 2,224 of them who died on this route in the first seven months of 2017 (International Organization for Migration, 2017). As many as 147,000 migrants crossed the SOUTH ROUTE border of Europe from the beginning of 2017 to 30th September of the same year. Of that 12,420 reached Spain, 23,974 Greece and 110,616 Italy. According to the UNHCR statistics, 5,096 migrants died or were reported missing on their way through the Mediterranean Sea in 2016, 3,771 in 2015 and 3,538 in 2014 (UNHCR, 2017).

Within the meaning of Schengen rules, migrants must ask for an asylum in the first country they enter. The waves of illegal migrants reaching the coast of Greece, Italy, Malta and Spain are in the asylum competence of these countries. It was mainly Greece that did not fulfill its role sufficiently, thus often enabling the migrants to continue their journey around Europe. If Italian or Greek, for instance, took their fingerprints they would automatically have to deal with their application for asylum.

The migration pressure in the above countries is also connected with the policy of resettling refugees amongst the EU states based on quotas, which are mostly enforced by the European Commissioner for Migration, Home Affairs and Citizenship Mr. Dimitris Avramopoulos (Greek) and by the High Representative of the European Union for Foreign Affairs and Security Policy Ms. Frederica Mogherini (Italian). The V4 countries do not have any intention to accept the quota system, which they vigorously defied in Brussels. The Vysegrad Four countries share the same attitude towards cooperation in the field of problem borders of the Balkan route, where the members of the Slovak policy forces also help. The building of fences, togetherness, less generous social benefits and, most importantly, a sceptic attitude towards migrants that they share discourage these travellers from settling in the V4 countries.

\section{Measures Preventing Migration}

The desperate situation of migrants trying to get to the European shore has forced the EU member states to change the system of EU external border and Schengen Area protection. The observation of the Dublin Convention seemed to be critical at land borders due to missing migrant records. The hotspots established in a hurry in Greece, France and Italy did not reflect the actual need. Later on, the waves of migrants headed deeper inside Europe causing troubles to all the affected countries on their journey. Due to inconsistent and, in some cases, completely missing records of migrants entering the Schengen Area, these had a chance to move around the given territory freely without any possibility to control them. Subsequent terrorist attacks in France or Belgium and demonstrations of violence in Germany, Sweden or Greece clearly showed that the solution has to, first and 
foremost, start on the outer border, i.e. in transit countries and countries of origin. Another considerable aspect of migration crisis mitigation and solving is the fight against organised groups of smugglers who mostly operate in the North Africa and in the waters of the Mediterranean Sea.

The critical document for the above steps is the 2015 European Agenda on Migration. In connection with the harmonisation of internal and external policies, the Agenda uses the potential of EU agencies and tools and involves member states, international organizations and third countries in its activities. In its agenda, the EU outlined the measures to be adopted immediately in order to react on the critical situation in the Mediterranean region. It further outlined the steps to be adopted in the years to come in order to control migration considering all its aspects. The Agenda has thus become a priority document dealing with migration, which was also confirmed by the High Representative of the European Union for Foreign Affairs and Security Policy Federica Mogherini who stated: „By this radical programme the European Union showed that it is ready to solve the situation of people running away from their countries due to wars, persecution and poverty. All the member states are responsible for migration and that is way all of them are now asked to contribute to the solution of this historic problem. It is not only Europe but the entire world that faces this problem. By this Agenda we confirm and extend our cooperation with the countries of origin and transit in order to save human lives, prevent any smuggler group activities and protect people in despair. We all know, however, that the actual and long-term reaction will only be possible once the main root causes are solved, starting with hunger and ending with an unstable situation caused by wars following crisis in Libya and Syria. The European Union has been involved and it is determined to cooperate with the international community in this field. " (European Commission, 2015b).

The European Agenda on Migration reacted on the migrant crisis by immediate measures and long-term measures called the four pillars of migration.

The 2015 agenda included the following activities in the series of immediate measures:

$>\quad$ Tripling capacities and sources for the Triton and Poseidon operations of the Frontex Agency in 2015 and 2016;

$>\quad$ Activation of an emergency system in accordance with article 78, paragraph 3 of the treaty in order to ensure better resettlement of those seeking asylum in Europe;

$>\quad$ New concept of hotspots: the Commission will coordinate the field cooperation of EASO, Frontex and Europol in the front-line member states in order to speed up migrant identification and registration and to take their fingerprints and coordinate their returns. 
$>\quad$ Mobilisation of another 60 million EUR financing package for the front-line member states;

System of resettlement with the budget of 50 million EUR for the transfer of 20,000 people to Europe in a safe and legal manner;

$>\quad 30$ million EUR for regional development and protection programmes (RDPP) that will be run in the north of Africa and in the Horn of Africa in 2015 and 2016;

$>\quad$ Exchange of intelligence information managed by Europol and supported by all the EU agencies with the aim to disintegrate criminal networks; Frontex and Europol will create profiles of vessels that smugglers might use;

$>\quad$ Operations of the common security and defence policy (CSDP) in the Mediterranean Sea region to pick up and destroy the above vessels;

$>\quad$ Migration will become a special part of the on-going missions of Common Security and Defence Policy (CSDP) already performed in Nigeria and Mali, which will be strengthened in terms of border management.

$>\quad$ Creating a pilot multi-purpose centre in Nigeria in cooperation with IOM and UNHCR;

$>\quad$ Including European liaison migration officers in EU delegations in key countries.

The main element of the European Agenda on Migration was the following four pillars of migration which have directed the EU activities to longer-term migrant crisis solving (European Commission, 2015a):

PILLAR No. 1 Reducing the incentives for irregular migration 283,532 illegal border crossings detected in 2014 (164\% increase compared to 2013):

$>\quad$ Action plan for intensifying the investigation and persecution of criminal groups, help with their disintegration, bringing criminals to justice and confiscation of their property.

$>\quad$ Return Handbook concerning the harmonisation of procedures for the return in all the member states.

$>\quad$ Stronger partnerships with third countries in connection with smuggling and return.

$>\quad$ Intensified involvement of EU delegations in the key countries.

$>\quad$ Stepping up the role of the Frontex Agency in connection with return operations.

PILLAR No. 2 Saving lives and securing the external borders In 2015 , almost 7,300 out of 24,000 migrants rescued in the Strait of Sicily were rescued by the forces deployed by Frontex:

$>\quad$ Modified proposal concerning 'smart borders'. 
$>\quad$ Financing initiatives in order to enforce the capacities of the northern African countries in relation to interventions and rescuing of migrants in despair.

$>$ Establishment of a European border guarding system to be considered.

$>\quad$ Stronger position of the Frontex Agency.

PILLAR No. 3 Strengthening the common asylum policy 626,715 asylum seekers in 2014 (45\% increase compared to 2013):

$>\quad$ Full implementation of the Common European Asylum System via a new monitoring/surveillance mechanism.

$>\quad$ Evaluation of the Dublin System by the end of the first half of 2016 in consideration of its revision.

$>\quad$ Determined initiatives to fight abuses of the asylum system.

$>\quad$ Considering the implementation of a single asylum procedure in order to ensure an equal treatment of the asylum seekers throughout Europe.

PILLAR No. 4 Developing a new policy on legal migration 17 million Schengen visas and 2.3 million of residence permits issued in 2013:

$>\quad$ Reviewing the EU Blue Card Directive.

$>\quad$ Creating a specialised platform for cooperation with the member states, enterprises and trade unions in the field of economic migration.

$>\quad$ Cheaper, faster and safer remittance transfers.

$>\quad$ Development of an 'Expression of Interest System' that would use verifiable criteria for initial potential automatic selection of migrants to be considered.

$>\quad$ Maximising benefits for the development of the countries of origin

The Frontex Agency plays an important role in border protection which is based on common operations of forces in Greece, Italy, Spain, Bulgaria, and in the West Balkan region. The agency performs various operations in Greece. The common operation Poseidon performed in the Aegean See has been supported by Greece in connection with border management and the performance of an approach based on hotspots located on Aegean See islands and the execution of the EU and Turkey statement. In connection with the common operation Poseidon, the agency deployed 866 officers, the support of activities in the field of readmission included, and 280 security officers co-funded by the agency have been deployed by the Greek police. There have also been three short see patrol vessels, two coastal patrol vessels, nine coastal patrol boats, one fixed-wing aircraft, two helicopters, 20 patrol vehicles, four buses and one thermal vision vehicle deployed. The Agency also supports Greece via common operations flexible operation activities and coordination centres for border management, all that by deploying 54 officers in total on the land borders of Greece with Turkey, Albania and Macedonia, a former Yugoslavian republic. Thanks to 
activities in the northern Greece border surveillance will be strengthened and irregular secondary movement will be prevented which will enforce the EU response to the Western Balkan route challenges. There are 17 officers deployed there at the moment. The approved plan, however, expects over 60 officers to be deployed, which means that there are still about 40 officers to be sent there. As part of the common operation Triton run in Italy and the middle part of the Mediterranean Sea the agency has deployed 345 officers, including the deployment of crew members and means and experts that help with putting the hotspot-based approach in practice. The deployment is supported by three aircrafts, two helicopters, two short sea patrol vessels, six coastal patrol vessels and three coastal patrol boats. On $3^{\text {rd }}$ of May 2017, the common operation Indalo 2017 started to support Spain's coordinated operation activities at coastal borders of the Western Mediterranean region, all that in the view of controlling irregular migrant flows heading for the EU and solve cross-border criminal activities. The agency also continues to help Bulgaria control the land border also in the view of preventing irregular secondary movements. The support is provided via common operations flexible operation activities and coordination centres at the Bulgarian land borders with Turkey and Serbia. There are currently 149 officers deployed that are supported by 11 teams of dog handlers, eight thermal vision vehicles, 41 patrol vehicles, eight $\mathrm{CO}_{2}$ detectors and 39 smart cameras. In other member states, there are 135 officers deployed at the moment. The goal is to help with border control in the West Balkan region. The most critical deployments are part of common operations - flexible activities at the Croatian and Hungarian land borders with Serbia. These are supported by ten teams of dog keepers, four thermal vision vehicles, 33 patrol cars, one $\mathrm{CO}_{2}$ detector and 12 smart cameras (European Commission, 2017). Collective protection, cooperation and crisis management in the Mediterranean Sea is ensured by the operation Sea Guardian led by NATO. The headquarters of the operation is in Northwood, Britain. The operation is currently focusing on three basic tasks: counter-terrorism at sea, providing support to maritime situational awareness and contributing to maritime security capacity building (North Atlantic Treaty Organization, 2017).

As part of the Pillar No. 1 on reducing the incentives for irregular migration, the EU resolved to fight criminal and smuggler groups. The reaction on this serious type of illegal activities was the new offshore operation EUNAVFOR MED Sophia that started in October 2015. This operation has helped to arrest 110 suspected smugglers and traffickers and to hand them over to Italian authorities and to 'neutralise' 470 vessels. This operation has also helped to save almost 40,000 lives. The task of the Sophia operation was to disrupt the business model of migrant smugglers and traffickers in the southern part of the Central Mediterranean region. The 
operation has two support tasks: training of Libyan coastal guards and naval forces and contribute to the application of the UN's arms embargo on the High Seas of the Libyan cost in accordance with UN's Security Council resolutions No. 2292 (2016) and 2357 (2017). In July 2017, the Council changed the mandate of the operation in order to (European Council, 2017b):

$>\quad$ Introduce a mechanism of training participant monitoring so as to ensure a long-term efficiency of Libyan coastal guard training.

$>\quad$ Perform new supervisory activities and gather information on illegal trading with the oil exported from Libya in accordance with resolutions of UN's Security Council No. 2146 (2014) and No. 2362 (2017).

$>$ Improve the possibility of exchanging information with the authorities enforcing the rights of the member states, FRONTEX and EUROPOL in the field of human trafficking.

Overview of migrant flows heading for the most affected EU countries (Italy and Greece) in a time horizon given and by individual nationalities can be seen in Fig. 2.

As part of international crisis management operations with either military or police forces involved, an effective health care support has been a strong success determinant of these operations. The officers of deployed forces understand very well the importance of early and complex health care provision. Possible early provision of urgent, life-saving health care greatly contributes to the performance of required tactical activities and to the willingness of soldiers to risk their health or even their lives. Of a special risk is the involvement of Slovak military police officers in the EUNAVFOR MED Sophia operation, which was the first naval operation that the Slovak Republic was involved in (Gubáš, 2016). 


\section{Migration flows: irregular arrivals} in Italy and Greece

\section{Irregular arrivals per month}

Border crossings by sea, 2015-2017

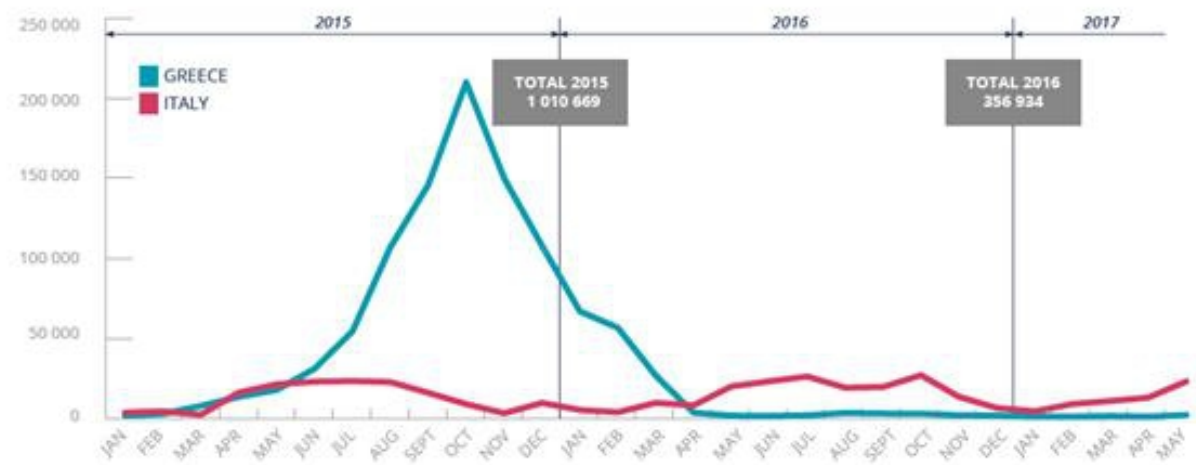

Irregular arrivals per nationality

Top nationalities:

January - Apeil 2017 (italy) I january - May 2017 (Greece)

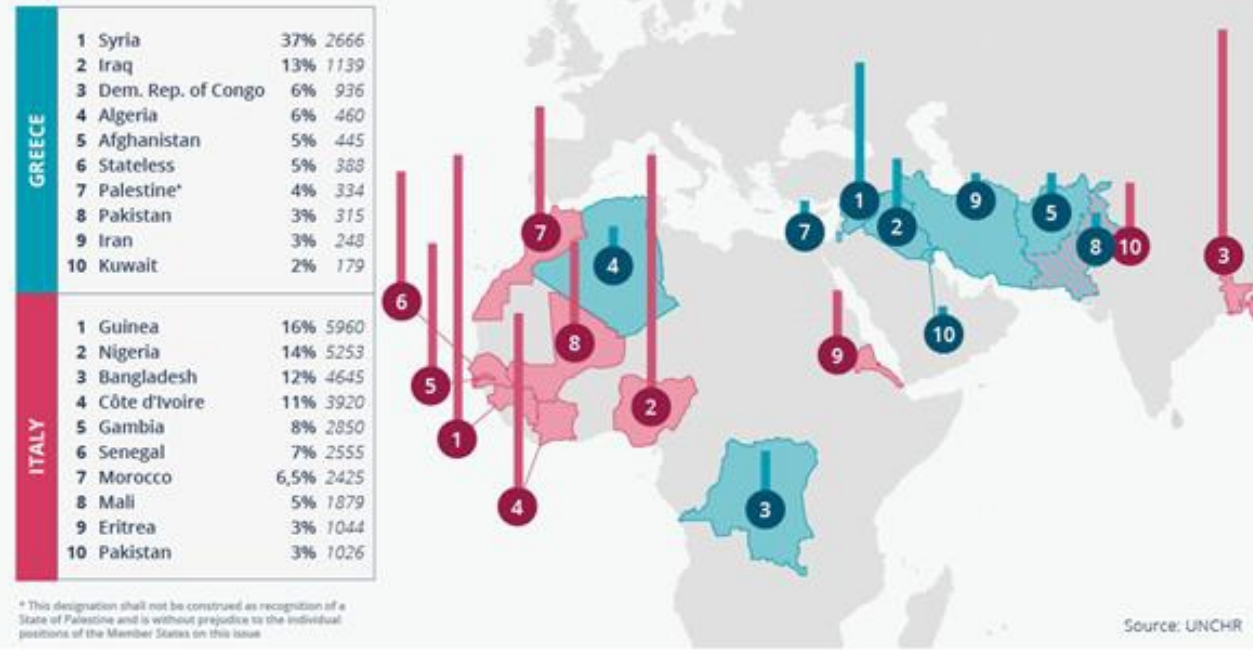

Fig. 2: Migration flows to Greece and Italy. (Source: European Council, 2017c)

\section{Measures to Combat Terrorism}

In today's ever changing and globalised world it is more and more difficult to predict the security situation. Its dynamics and an increase of asymmetric types of threats that can be seen lately show that it is necessary 
to ensure their regular and continuous analysis. The security environment can only be changed if known well. The security of a state may only be ensured by continuously influencing its security environment (Marhevka, 2016).

A strongly resonating connection between migration and terrorism has intensified lately. The activities of so-called 'lone actors', acts of terrorist groups or cybernetic attacks on strategic institutions mostly endanger the security of Western European citizens. The massive influxes of migrants in EU countries in 2015 and with that connected terrorist attacks have forced the member states and the representatives of the EU to adopt decisive measures.

It is understandable that the European Union has been going through not only migrant but also terrorist crisis since the last terrorist attacks. The interconnection and relationship of the two has been confirmed by the terrorist attacks in Paris, Belgium or Germany. The migrant can be a terrorist hiding behind a crowd of migrants and the terrorist is a potential migrant ready to attack Europeans. The fact is that the attacks in Paris were carried out by European citizens. Despite that, insufficient border security and extreme waves of migrants were claimed to be the initial reasons of these attacks. The position of a refugee or a migrant has been forcing the countries taking migrants to intensify social inclusion, hospitality and free mobility. Terrorist groups, on the other hand, suppress the form of a nation state thus leading country towards social exclusion, limited mobility, religious and ethnic extremism and xenophobia. Hyper-religious nationalism influences, in the form of terrorism, nation states and moves their borders of liberal democracy closer to authoritative states of military law. A very good example of the above facts is the announcement of French 'state of emergency' and the deployment of thousands of soldiers following the Paris attacks (Nail, 2016).

Terrorism as one of many forms of armed violence is nothing new. It has, however, changed very dramatically, especially in connection with the occurrence and termination of the bipolar world order. The $11^{\text {th }}$ of September 2001 is perceived as a milestone in the development of terrorism and security of the world. A surprising force of the September terrorist attack has emphasised how important it is to fight terrorism. The terrorism, however, should not be responded to by revenge as this mostly affects innocent ones when looking at it from the historical perspective. It is also not suitable to create an atmosphere full of stress and panic. Such atmosphere would not only support the idea terrorists are spreading but would also create space for forces that might intensify violence (Škvrnda, 2002).

According to some experts, the milestone of terrorist attacks in Europe were the Summer Olympic Games in Munich in 1972. At that time, 
a group of Palestinian terrorists belonging to the Black September Organization attacked and took Israeli athletes as hostages. They said they would release them in exchange for more than 200 Palestinian prisoners being held by Israel. The whole incident had tragic consequences with 11 Israeli athletes dying (Encyclopedia Britanica, 1972). The numbers of terrorist attack victims in Western Europe since 1970 can be seen in Fig. 3.

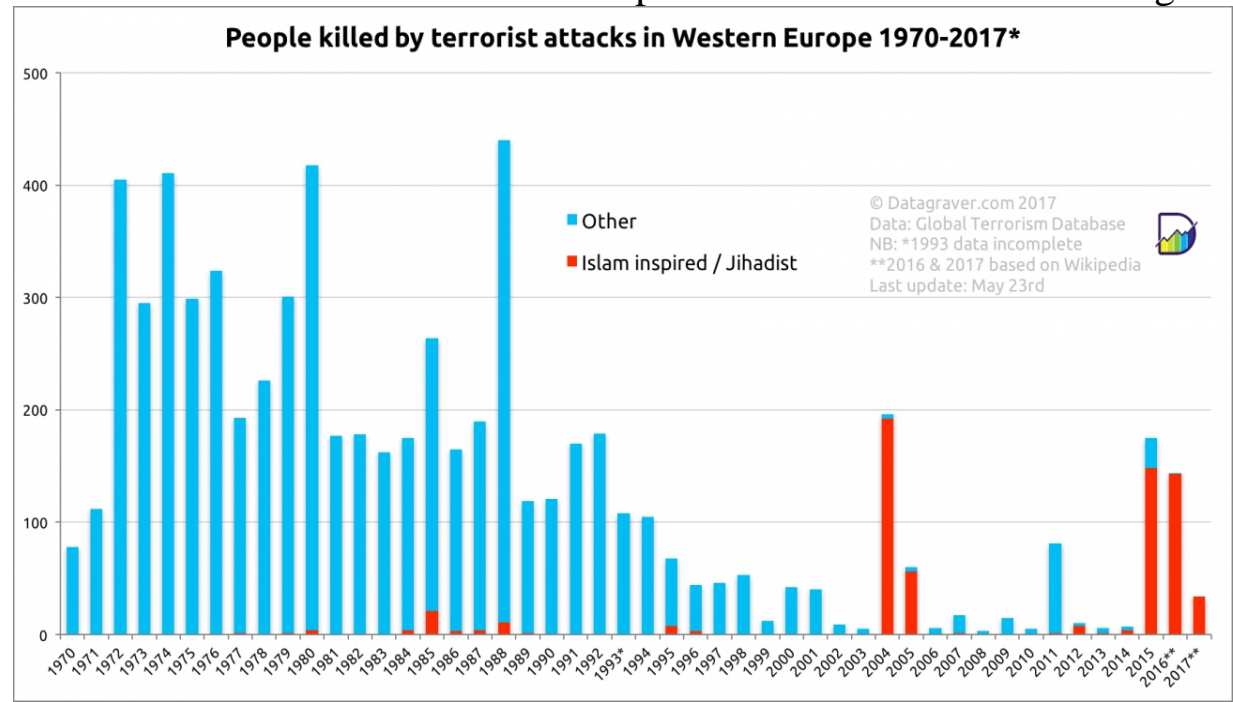

Fig. 3: People killed by terrorist attacks in Western Europe 1970-2017. (Source:

Datagraver, 2016)

On the basis of the presented graph, the source documents for which come from the Global Terrorist Database, it can be confirmed that the migrant crisis has closely related to the acts of terrorism in Europe since its beginning in 2014. Compared to the terrorism carried out by 'unincorporated' groups or individuals, the years 2015, 2016 and 2017 show a high rate of terrorist activities motivated by Islamic radicalism.

The $11^{\text {th }}$ September 2001 attacks were one of the drivers that made the EU Council adopt the EU Anti-Terrorism Strategy in order to fight terrorism globally and increase security in Europe. The strategy focuses on the following four pillars:

$\begin{array}{ll}\text { - } & \text { prevent, } \\ \text { - } & \text { protect, } \\ \text { - } & \text { pursue, } \\ \text { - } & \text { respond } \text {. }\end{array}$

The EU key priority in the case of the PREVENT pillar is to solve the causes of radicalisation and terrorist recruitment. For that purpose, the EU Council adopted the EU Strategy for Combating Radicalisation and Recruitment to Terrorism in 2008. In connection with security situation development (with the focus on lone actors and foreign fighters' attacks and 
the use of social media by terrorists) the strategy was reviewed in June 2014. The second priority of the EU strategy in the PROTECT pillar is to protect citizens and infrastructure and to reduce the vulnerability to attacks. This includes securing external borders, improving transport security, protecting strategic targets and reducing the vulnerability of critical infrastructure. In this area, the EU adopted a directive regulating the use of passenger name record (PNR) data in April 2016. Member states will have to comply with the new rules within two years. As part of the PURSUE pillar the EU is trying to hinder terrorists' capacity to plan and organise, and to bring these terrorists to justice. To achieve these goals, the EU has focused on strengthening national capabilities, improving cooperation and information exchange between police and judicial authorities, tackling terrorist financing, and depriving terrorists of their means of support and communication. In May 2015, the Council and the European Parliament adopted new rules to prevent money laundering and terrorist financing. The fourth pillar of the Counter-Terrorism Strategy, i.e. the RESPOND pillar, is to prepare for, manage and minimise the consequences of a terrorist attack. This is done by improving capabilities to deal with the aftermath, the coordination of the response, and victims' needs. The priorities in this area include the development of EU crisis coordination arrangements, revision of the civil protection mechanism, development of risk assessment tools and sharing of best practices on assistance to victims of terrorism (European Council, 2017a).

The strategy stresses both, the pillars and cooperation with third countries and international institutions, as the EU security is closely linked with the situation in other countries, especially those neighbouring the EU. The crucial component of the EU strategy is cooperation with the USA. In this field, there have been treaties signed in the field concerning terrorism financing, transport and borders, mutual legal help and extradition. The USA bodies have intensified their cooperation with Europol and Eurojust ${ }^{2}$. The EU also cooperates with the UN and the Global Counter-Terrorism Forum as well as with regional organizations such as the Organization for Security and Co-operation in Europe, League of Arab States and Organisation of Islamic Cooperation (European Council, 2017a).

The Slovak Republic too has responded to the worsened security situation related to terrorism. As of $1^{\text {st }}$ January 2016, a new counterterrorism legislation stipulating the Constitution and amending 16 acts in

${ }^{2}$ Eurojust is a unit of the European Union for judicial cooperation. It supports judicial coordination and cooperation amongst internal authorities in combating serious organised criminal activities influencing more than just one EU member state. The unit was established in 2002 and it has 240 employees. Its board comprises individual member state representatives (European Union, 2017). 
connection with terrorism became applicable. Moreover, a CounterTerrorism Unit forming a part of the National Criminal Agency structure was established on $1^{\text {st }}$ February 2017 (by merging the Counter-Terrorism Department and the Extremism and Audience Violence Department) as a reaction on the 2016 amendment of the Criminal Act and Criminal Procedure Code. The goal of the unit is to centralise the fight against extremism and terrorism in the Slovak Republic and make it more efficient.

Nowadays, there is nothing that can excuse terrorism which may only be fought by reacting on its causes. Is really everything we call terrorism the actual terrorism? A big question related to its combating is also the respecting of human rights. Combating terrorism may not lay the basis of its breach. The introduction of measures with extensive impact does not guarantee a higher level of safety and may even damage the basis of current society functioning (Škvrnda, 2002).

\section{Conclusion}

It can be stated that the wave of migrants coming to Europe probably culminated in the autumn 2015 reaching its record of 200 thousand migrants crossing the Greek border in October. The March 2016 treaty signed by the EU and Turkey and concerning the migrant crisis has gradually released the tension on the Balkan route. Then, a wave of migrants attacked the shore of Italy and Spain. At that time, the mainland countries of the EU and Schengen Area had already been 'flooded' with hundreds of thousands of migrants. Simultaneously with migrant crisis demonstrations, the Islamic State started to act violently. The terrorist attacks in France and Belgium have speeded up the need to embrace the criticality of the situation in the European Parliament and adopt measures for border protection and keeping member states secure. An agenda on migration was adopted, common sea and land operations were introduced to strengthen the border and eliminate smuggling and trafficking. In individual states, security forces were supported with material and technical supplies and new resources and the applicable legislation has been partially adjusted to the security situation given. When looking at the migrant crisis from the humanitarian perspective the fundamental obligation is to provide help to those refugees who, unlike economic migrants that managed to polarise the states of the west and east of Europe, had existential reasons for their journey. A special attitude has been adopted by the former Vysegrad Four countries that resolutely refused the migrant quotas and were in favour of the most radical solution of external border protection from the very beginning of the crisis.

The migrant crisis, however, helped Europe to a certain extent and it was not just in the form of better future demographic curve and staffing badly paid jobs on the labour market. In the figurative sense, if it had not 
been for the crisis the society would have been less security-conscious, comfort would have outweighed vigilance and security would have been taken for granted. The limits represented by common security solutions related to migration and their observance and the economic situation led to Brexit. The migrant crisis was a trigger for deepening the dialogue about Europe's future and possible regional cooperation that could support economic growth and security considering potential interaction of civilisations in the future.

\section{References:}

1. Škvrnda, F. (2002). Terorizmus. Najvýznamnejšia nevojenská bezpečnostná hrozba súčasnosti. Bratislava: Generálny štáb ozbrojených síl Slovenskej republiky, štáb personálneho manažmentu.

2. Nail, T. (2016). A Tale of Two Crises: Migration and Terrorism after the Paris Attacks. In Studies in Ethnicity and Nationalism. Nations and Nationalism. Volume 16, Issue 1 (pp. 158-167) Retrieved from http://onlinelibrary.wiley.com/journal/10.1111/(ISSN)1754-9469

Gubáš, F. (2016). Niektoré aspekty výstavby vojenského zdravotníckeho zariadenia pre jednotky určené na nasadenie do operácií medzinárodného krízového manažmentu. In Národná a medzinárodná bezpečnost’ 2016. Zborník vedeckých a odborných prác, (pp. 118-122). Liptovský Mikuláš: Akadémia ozbrojených síl gen. M. R. Štefánika. Marhevka, M. (2016). Možné prístupy $\mathrm{k}$ hodnoteniu bezpečnostného prostredia štátu. In Národná a medzinárodná bezpečnost' 2016. Zbornik vedeckých a odborných prác, (pp. 269-279). Liptovský Mikuláš: Akadémia ozbrojených síl gen. M. R. Štefánika.

Encyclopedia Britannica (1972). Munich massacre. Retrieved from https://www.britannica.com/event/Munich-Massacre

3. European Commission (2015a). Európska migračná agenda 2015 štyri piliere na lepšie riadenie migrácie [Brochure]. Retrieved from http://www.hrl.sk/sites/default/files/files_downloads/summary_europ ean_agenda_on_migration_sk.pdf

4. European Union (2017). Jednotka Európskej únie pre justičnú spoluprácu (Eurojust). Retrieved from

5. https://europa.eu/european-union/about-eu/agencies/eurojust_sk

6. European Commission (2015b). Lepšie riadenie migrácie vo všetkých jej aspektoch: Európska migračná agenda [Press release]. Retrieved from

7. http://europa.eu/rapid/press-release_IP-15-4956_sk.htm 
8. European Council (2017a). Stratégia EÚ na boj proti terorizmu. Retrieved from

9. http://www.consilium.europa.eu/sk/policies/fight-againstterrorism/eu-strategy/

10. European Commission (2017). Tretia správa komisie Európskemu parlamentu, Európskej rade a Rade osfunkčnení európskej pohraničnej a pobrežnej stráže. Retrieved from

11. http://eur-lex.europa.eu/legalcontent/SK/TXT/?uri=CELEX:52017DC0219

12. European Council (2017b). Operácia EUNAVFOR MED SOPHIA: mandát predľzený do 31. decembra 2018. Retrieved from

13. http://www.consilium.europa.eu/sk/press/press-releases/2017/07/25eunavformed-sophia-mandate-extended/

14. International Organization for Migration (2017). The Central Mediterranean route: Migrant Fatalities January - July 2017. Retrieved from

15. http://gmdac.iom.int/the-central-mediterranean-route-migrantfatalities-january-july-2017

16. North Atlantic Treaty Organization (2017). Operation Sea Guardian. Retrieved from

17. https://www.nato.int/cps/ua/natohq/topics_136233.htm\#

18. UNHCR (2017). Mediterranean Situation. Retrieved from

19. http://data2.unhcr.org/en/situations/mediterranean\#_ga=2.262773067 .653129152.1509310273-1962311708.1496781635

20. Datagraver (2016). People killed by terrorism per year in Western Europe 1970-2015. Retrieved from

http://www.datagraver.com/case/people-killed-by-terrorism-per-yearin-western-europe-1970-2015

21. Dosani, S. (2015). Five charts that help explain Europe's migrant crisis. Retrieved from

22. http://america.aljazeera.com/watch/shows/compass/articles/2015/5/7/ five-charts-that-help-explain-europes-migrant-crisis.html

23. European Council (2017c). Infografika - irregular arrivals in Italy and Greece. Retrieved from

24. http://www.consilium.europa.eu/sk/infographics/irregular-arrivalsitaly-greece-06-2017/ 